\title{
PENGARUH ETIKA KERJA ISLAM, KEPEMIMPINAN \\ TRANSFORMASIONAL DAN MOTIVASI KERJA TERHADAP \\ KINERJA KARYAWAN DI KJKS BMT LOGAM MULIA GROBOGAN
}

\author{
Amirus Sodiq
}

\section{IAIN Kudus}

\begin{abstract}
This research aims to determine the effect of Islamic work ethics, transformational leadership and work motivation on employee performance, this research was conducted using a quantitative approach with multiple linear regression analysis, where previously classical assumptions were tested, namely normality test, heteroscedasticity test, autocorrelation test and multicollinearity test, the results of multiple linear regression analysis concluded that Partially Islamic Work Ethics (X1) have no significant effect on employee performance, Transformational Leadership (X2) has a significant effect on employee performance, and partially Work motivation (X3) has a significant effect on employee performance
\end{abstract}

Keywords: Islamic Work Ethics, Transformational Leadership, Work Motivation, Performance

\section{A. PENDAHULUAN}

Hingga pertengahan 2015, pertumbuhan perbankan syariah di Indonesia telah mengalami perkembangan yang cukup signifikan, dimana volume usaha bank umum syariah telah mencapai Rp. 272,4 Triliun, sedangkan volume usaha bank pembiayaan rakyat syariah mencapai Rp. 6,8 Triliun, atau secara keseluruhan volume usaha perbankan syariah telah mencapai Rp. 279,2 Triliun, dengan kata lain mengalami peningkatan sebesar 8,3\% (yoy) dibanding volume usaha tahun 2014 yang mencapai Rp. 257,8 Triliun. (SPS Juni, 2015).

Dalam hal pasar tenaga kerja, pertumbuhan pekerja pada perbankan syariah hingga pertengahan 2015 telah mencapai 47.529 pekerja, dengan komposisi 38.307 pekerja di Bank Umum Syariah, 4.414 pekerja di Unit Usaha Syariah dan 4.808 pekerja di Bank Pembiayaan Rakyat Syariah. Sedangkan jumlah pekerja pada perbankan syariah hingga pertengahan 2014 telah mencapai 48.937 pekerja, 
dengan komposisi 29.232 pekerja di Bank Umum Syariah, 14.811 pekerja di Unit Usaha Syariah dan 4.894 pekerja di Bank Pembiayaan Rakyat Syariah. Ini menunjukkan bahwa pertumbuhan tenaga kerja pada perbankan syariah tahun 2015 mengalami penurunan sebesar $-2.8 \%$.

Salah satu unsur terpenting yang dijadikan acuan baik oleh individu maupun perusahaan sebagai pedoman dalam melaksanakan aktivitas bisnisnya adalah etika kerja, hal itu dilakukan agar kegiatan yang mereka lakukan tidak mengalami kerugian secara individual ataupun kelembagaan (Rudito dan Melia, 2007: 6). Etika diperlukan oleh sumber daya manusia khususnya perusahaan di dalam lembaga keuangan seperti Baitul Mal wat Tamwil. Mengingat BMT merupakan bagian dari lembaga keuangan yang menerapkan konsep syariah, maka etika yang dipakai oleh para agen adalah etika kerja Islam. Etika kerja Islam memegang peranan penting dalam kegiatan perusahaan yaitu untuk mencapai target atau profit duniawi maupun ukhrawi (falah).

Beberapa tahun terakhir ini, kajian etika kerja memiliki daya tarik yang sangat kuat bagi para pengamat, peneliti, juga akademisi, seiring dengan kegagalan beberapa perusahaan raksasa seperti Enron dan WorldCom. Walaupun demikian kajian ini yang sejatinya masuk dalam ranah etika bisnis telah dilakukan di beberapa negara Eropa dan Amerika, hanya saja kajian-kajian tersebut berpijak pada etika kerja protestan yang pernah diusung oleh Max Weber. (Rokhman, 2010).

Namun demikian, penelitian dan kajian-kajian yang dilakukan di beberapa negara Eropa dan Amerika tentu tidak bisa dilakukan di negara-negara yang mayoritas penduduknya beragama Islam, hal itu disebabkan karena Islam mempunyai konsep etika bisnis yang bersumber dari Al-Qur'an dan hadits, sehingga ada beberapa elemen yang tidak bisa disatukan karena adanya perbedaan dengan etika kerja protestan yang diusung oleh Weber, dan etika kerja Islam itulah yang telah mengantarkan umat Islam mencapai kejayaannya pada abad VIII - XIV M. (Ali, 2010).

Menurut Hartanto (2009: 512) kepemimpinan transformasional merupakan suatu cara untuk mempengaruhi orang lain sedemikian rupa sehingga mereka mau 119

Jurnal Bisnis dan Manajemen Islam 
dan rela mengeluarkan kebijakan dan kapabilitas terbaiknya di dalam proses penciptaan nilai. Sedangkan Luthans (2006: 653) menyatakan bahwa kepemiminan transformasional membawa keadaan menuju kinerja yang lebih tinggi pada organisasi yang menghadapi tuntutan pembaharuan dan perubahan. Dengan demikian kita dapat menyimpulkan bahwa kepemimpinan transformasional mampu menciptakan karyawan untuk senantiasa memiliki kinerja yang tinggi dan mampu membawa perusahaan kearah yang lebih baik dalam menghadapi dunia yang semakin kompetitif.

Motivasi kerja yang tinggi dari karyawan merupakan suatu hal yang diinginkan oleh setiap perusahaan. Karyawan yang memiliki motivasi kerja akan bekerja secara optimal dalam menyelesaikan setiap pekerjaan, dan bekerja dengan penuh tanggung jawab sesuai dengan pekerjaan yang diberikan oleh perusahaan. Faktor motivasi kerja karyawan harus mendapatkan perhatian dari pemimpin perusahaan. Penurunan motivasi kerja dari karyawan akan berdampak negatif pada kinerjanya, sehingga secara tidak langsung menimbulkan masalah pada stabilitas perusahaan.

Selain masalah motivasi kerja karyawan, faktor kepemimpinan juga dapat menjadi masalah bagi karyawan yang akan berdampak pada kinerjanya. Pemimpin harus bertindak proaktif dalam menyelesaikan masalah yang dihadapi oleh seluruh komponen perusahaan. Pemimpin harus mampu menjadi teladan bagi pengikut atau bawahannya. Seperti halnya kepemimpinan transformasional dimana seorang pemimpin harus dapat memberikan pengaruh yang positif terhadap kinerja dan sikap pengikut.

Pemberian motivasi kerja oleh seorang pemimpin merupakan tindakan positif yang dapat menimbulkan dorongan atau semangat kerja bagi pengikutnya. Karyawan akan memberikan kontribusinya atau kinerja yang optimal bagi perusahaan apabila mereka merasa dihargai dan ikut dilibatkan secara langsung dalam memajukan organisasi.

Penelitian yang dilakukan oleh Rokhman (2010), Ahmad (2011), Shafique et. al (2015) menjelaskan bahwa etika kerja Islam mempunyai pengaruh yang signifikan terhadap kinerja karyawan yang diukur dengan kepuasan kerja dan 
komitmen organisasi, sedangkan penelitian yang dilakukan oleh Shafissalam dan Azzuhri menjelaskan bahwa etika kerja Islam tidak berpengaruh terhadap kinerja karyawan.

Penelitian tentang pengaruh kepemimpinan transformasional terhadap kinerja karyawan pernah dilakukan oleh Bushra, et. al.(2011), Indica (2013) dan Ekaningsih (2014) menjelaskan bahwa kepemimpinan transformasional berpengaruh positif terhadap kinerja karyawan, sedangkan penelitian Natsir (2005) menyatakan bahwa kepemimpinan transformasional berpengaruh negative terhadap kinerja karyawan.

Penelitian tentang pengaruh motivasi kerja terhadap kinerja karyawan pernah dilakukan oleh Hamid (2012) di Bank Syariah mandiri kantor cabang Makassar, Murti dan Veronika (2013) di PDAM kota Madiun, serta Permanasari (2013) di PT Anugrah Raharjo Semarang menjelaskan bahwa motivasi kerja berpengaruh positif terhadap kinerja karyawan.

Penelitian-penelitian sebelumnya mengenai pengaruh motivasi kerja dan kepemimpinan transformasional menunjukkan hasil yang positif dan signifikan. Agusthina, dkk (2011) yang meneliti tentang kinerja menemukan bahwa motivasi dan gaya kepemimpinan transformasional berpengaruh positif dan signifikan terhadap kinerja. Penelitan tersebut juga sejalan dengan penelitian yang dilakukan oleh Jung (2002), hasil penelitiannya menunjukkan bahwa para pemimpin yang menampilkan komponen kepemimpinan transformasional dipandang lebih efektif dan kinerja lebih tinggi dari pada para pemimpin yang tidak transformasional.

Sementara itu penelitian yang dilakukan oleh Brahmasari (2008), mengatakan bahwa motivasi kerja berpengaruh positif tetapi tidak signifikan terhadap kinerja, meskipun motivasi kerja berpengaruh positif dan signifikan terhadap kepuasan kerja tetapi belum tentu memengaruhi kinerja. Selain itu penelitian yang dilakukan oleh Komardi (2009), menunjukkan bahwa kepemimpinan transformasional dari atasan tidak berpengaruh signifikan terhadap kinerja pegawai, tetapi kepemimpinan transformasional terbukti berpengaruh signifikan terhadap motivasi kerja, dan motivasi kerja berpengaruh secara signifikan terhadap kinerja individu pegawai. 
Hasil penelitian dari para peneliti terdahulu menunjukkan bahwa terjadi perbedaan hasil penelitian tentang pengaruh etika kerja Islam dan kepemimpinan transformasional terhadap kinerja karyawan, perbedaan inilah yang mendorong peneliti untuk melakukan penelitian tentang pengaruh etika kerja Islam, kepemimpinan transformasional dan motivasi kerja terhadap kinerja karyawan di KJKS BMT Logam Mulia Grobogan.

Berdasarkan latar belakang masalah yang telah diuraikan di atas, maka pokok-pokok permasalahan dalam penelitian ini, Pertama, Apakah terdapat pengaruh etika kerja Islami terhadap kinerja karyawan KJKS BMT Logam Mulia Grobogan? Kedua, Apakah terdapat pengaruh kepemimpinan Transformasional terhadap kinerja karyawan KJKS BMT Logam Mulia Grobogan? Ketiga, Apakah terdapat pengaruh motivasi kerja terhadap kinerja karyawan KJKS BMT Logam Mulia Grobogan?

Berdasarkan rumusan masalah di atas, maka penelitian ini bertujuan: Pertama, Untuk menganalisis pengaruh etika kerja Islami terhadap kinerja karyawan KJKS BMT Logam Mulia Grobogan Kedua, Untuk menganalisis pengaruh kepemimpinan Transformasional terhadap kinerja karyawan KJKS BMT Logam Mulia Grobogan. Ketiga, Untuk menganalisis pengaruh motivasi kerja terhadap kinerja karyawan KJKS BMT Logam Mulia Grobogan.

\section{B. PEMBAHASAN}

\section{Etika Kerja Islam}

Etika berasal dari kata Yunani ethos (bentuk tunggal) yang berarti: tempat tinggal, padang rumput, kandang, kebiasaan, adat, watak, perasaaan, sikap dan cara berpikir. Bentuk jamaknya adalah ta etha, yang berarti adat istiadat. Dalam hal ini, kata etika sama pengertiaannya dengan moral. Moral berasal dari kata latin: mos (bentuk tunggal), atau mores (bentuk jamak) yang berarti adat istiadat, kebiasaan, wata, tabiat, akhlak dan cara hidup.(Agoes, 2009: 26).

Etika kerja merupakan acuan yang dipakai oleh individu atau perusahaan sebagai pedoman dalam melaksanakan aktivitas bisnisnya, agar kegiatan yang mereka lakukan tidak mengalami kerugian bagi individu atau lembaga yang lain. Etika kerja Islam adalah perilaku karyawan yang sesuai dengan apa yang BISNIS, Vol 6, No. 1 ,Juni 2018 
dianjurkan di dalam Al-Qur'an dan As-sunah (Ahmad, 2003: 27). Dengan kata lain Etika kerja yang Islami adalah serangkaian aktivitas bisnis dalam berbagai bentuknya yang tidak dibatasi jumlah kepemilikan hartanya (barang/jasa), namun dibatasi dalam cara memperolehnya dan pendayagunaan hartanya karena aturan halal dan haram (Muhammad danAlimin, 2004: 57).

Baik al-Qur'an maupun hadits telah memberikan resep tertentu dalam masalah tatakrama dan merekomendasikannya untuk kebaikan perilaku dalam masalah bisnis. Seorang pelaku bisnis Muslim diharuskan untuk berperilaku dalam bisnis mereka sesuai dengan apa yang dianjurkan Al-Qur'an dan Sunnah. Adapun tatakrama perilaku bisnis dirangkum dalam tiga garis besar yaitu murah hati, motivasi untuk berbakti dan ingat Allah dan prioritas utama-Nya (Ahmad, 2003: 109).

Etika kerja Islam mengandung dua dimensi, yaitu dimensi ukhrawi dan duniawi. Dalam aspek ukhrawi, Islam menekankan pentingnya niat dalam melakukan pekerjaan, tentu dengan tujuan untuk mendapatkan keutamaan dari Allah, bekerja yang didasarkan pada prinsip agama akan menunjukkan fithrah seorang muslim, dan mengangkat derajat dan martabat seseorang sebagai hamba Allah dapat dipercaya. Sedangkan dalam dimensi duniawi, agama menekankan konsep ihsan dan itqon dalam bekerja, ihsan berarti membawa kemaslahatan bagi diri sendiri dan orang lain, sedangkan itqon melakukan pekerjaan dengan teliti, professional, dan tanggungjawab (Ahmad dan Owoyemi, 2012).

Etika kerja yang bagus yang dimiliki oleh karyawan pada suatu perusahaan akan membuahkan efektifitas dalam bekerja, tanggungjawab, dan keinginan untuk melakukan inovasi dalam pekerjaannya, sehingga dalam skala global akan meningkatkan kinerja perusahaan secara keseluruhan, sebagaimana yang telah dinyatakan oleh para peneliti bahwa etika kerja Islam berpengaruh kepada kinerja karyawan.

Beberapa criteria yang merupakan unsure penting dalam etika kerja Islam dapat disederhanakan sebagai berikut: Visi dan misi bekerja yang diterapkan dalam niat bekerja dengan tujuan untuk mencari keutamaan atau ridha Allah, memperhatikan aspek halal dan haram. Tanggung jawab dalam bekerja yang 
diaplikasikan pada sifat amanah (dapat dipercaya) dan kepedulian social. Profesionalisme yang diwujudkan dalam bentuk kesabaran, efisiensi dan efektivitas, ketekunan dan tepat waktu.(Ali, 2001)

\section{Kepemimpinan Transformasional}

Kepemimpinan merupakan kemampuan seorang pemimpin untuk mempengaruhi dan mengarahkan pengikutnya dalam upaya mencapai tujuan organisasi. Seorang pemimpin harus mampu memberikan contoh serta memberikan motivasi kepada pengikutnya. Dalam perkembangannya, Burns mengklasifikasikan kepemimpinan menjadi transaksional dan transformasional (Bass dan Riggio, 1994: 3).

Pemimpin transformasional adalah pemimpin yang dapat memberikan pengaruh positif terhadap kinerja dan sikap pengikut. Hal senada juga diungkapkan oleh Bass bahwa Pemimpin transformasional adalah pemimpin yang memotivasi pengikutnya untuk mencapai kinerja yang melampaui harapan. Kepemimpinan transformasional mendorong pengembangan, interaksi, dan motivasi bawahannya (Griffin and Rafferty, 2004).

Hal senada juga diungkapkan oleh Robbins bahwa Pemimpin transformasional mendorong bawahannya agar lebih inovatif dan kreatif. Para pemimpin transformasional dipandang lebih efektif karena mereka lebih kreatif, mereka juga lebih efektif karena mampu mendorong pengikutnya menjadi kreatif. Pemimpin transformasional menghasilkan komitmen di pihak para pengikut dan menanamkan pada diri mereka rasa percaya yang lebih besar kepada pemimpin. Pemimpin transformasional menaruh perhatian terhadap pengembangan diri para pengikutnya, mengubah kesadaran para pengikut atas isu-isu yang ada dengan cara membantu orang lain memandang masalah lama dengan cara yang baru, serta mampu menyenangkan hati para pengikutnya untuk bekerja keras guna mencapai tujuan-tujuan bersama (Robbins dan Judge, 2008: 92). 


\section{Motivasi Kerja}

Motivasi diartikan Manulung sebagai suatu hal atau keadaan yang dapat menimbulkan dorongan bagi seseorang untuk bertindak atau melakukan sesuatu dengan cara tertentu (Manullang, 1982: 76), sehingga dalam memotivasi karyawan, manager harus mengetahui motivasi yang diinginkan karyawannya sehingga karyawan mau bekerja dengan senang hati demi tercapainya tujuan.

Herzberg menjelaskan bahwa factor motivasi mencakup beberapa aspek, diantaranya: gaji, kualitas supervise, kondisi kerja, jaminan kerja, hubungan antar pribadi, pengakuan dan peningkatan dalam pekerjaan Hasibuan, (Malayu, 1990: 177). Setiap individu memiliki kondisi internal, dimana kondisi tersebut turut berperan dalam setiap aktivitas maupun kinerja individu tersebut.

Kondisi internal tersebut salah satunya adalah motivasi kerja. Faktor motivasi kerja karyawan akan muncul dari dalam diri karyawan itu sendiri. Motivasi kerja merupakan dorongan untuk mengeluarkan tingkat upaya yang tinggi demi mencapai kinerja yang maksimal dan kepuasan kerja individu. Motivasi kerja yang tinggi dari karyawan sangat diharapkan oleh perusahaan, karena hal tersebut sangat membantu perusahaan dalam mencapai tujuan organisasi.

Vroom (1964) dalam Robbins (2008: 256) mengemukakan motivasi kerja yang berupa teori harapan (expectancy theory) yaitu kekuatan dari suatu kecenderungan untuk bertindak dalam cara tertentu, bergantung pada kekuatan dari suatu harapan bahwa tindakan tersebut akan diikuti dengan hasil yang ada dan pada daya tarik dari hasil itu terhadap individu tersebut. Teori harapan mengatakan bahwa karyawan akan termotivasi untuk mengeluarkan tingkat usaha yang tinggi ketika mereka yakin bahwa usaha tersebut akan menghasilkan penilaian kinerja yang baik.

Sedangkan Maslow (1970) dalam Uno (2012:41) mengembangkan teori motivasi berdasar hirarki kebutuhan manusia yang disusun dalam lima kategori menurut prioritas sebagai berikut : Phsyilogical Needs (kebutuhan fisologis), yaitu kebutuhan yang harus dipuaskan untuk dapat tetap hidup, seperti makanan, perumahan, pakaian dan sebagainya. Safety Needs (kebutuhan rasa aman), yaitu 
kebutuhan akan keselamatan, termasuk merasa aman dari setiap jenis ancaman fisik atau kehilangan, serta merasa terjamin. Social Needs (kebutuhan sosial), meliputi kebutuhan akan perasaan diterima oleh orang lain, perasaan dihormati, perasaan maju atau berprestasi dan kebutuhan akan perasaan ikut serta (sense of participation). Esteem Needs (kebutuhan akan penghargaan), yaitu kebutuhan akan harga diri maupun kebutuhan akan pengakuan dari orang lain. Self Actualization Needs (kebutuhan aktualisasi diri), yaitu kebutuhan untuk mewujudkan diri "yaitu kebutuhan mengenai nilai dan kepuasan yang didapat dari pekerjaan".

Alderfer (1972) dalam Agusthina (2011:843) mengemukakan indikator motivasi kerja dalam teori ERG yaitu: Pertama, Existence (kebutuhan akan keberadaan) Kebutuhan yang berhubungan dengan kelangsungan hidup yang meliputi kebutuhan akan keuangan terpenuhi. Kedua, Relatedness (kebutuhan relasi) Menekankan pentingnya hubungan sosial dan hubungan antar pribadi yang meliputi hubungan pimpinan dengan bawahan, hubungan pimpinan dengan pimpinan, dan hubungan rekan kerja. Ketiga, Growth (kebutuhan pertumbuhan) Kebutuhan yang berhubungan dengan keinginan intrinsik individu terhadap perkembangan pribadi.

Selanjutnya Mangkunegara (2005:101) mengemukakan bahwa terdapat dua teknik memotivasi kerja pegawai yaitu: Pertama, Teknik pemenuhan kebutuhan pegawai, artinya bahwa pemenuhan kebutuhan pegawai merupakan fundamen yang mendasari perilaku kerja. Kedua, Teknik komunikasi persuasif, adalah merupakan salah satu teknik memotivasi kerja pegawai yang dilakukan dengan cara mempengaruhi pegawai.

Sedangkan Siagian (2002:94) menambahkan bahwa dalam kehidupan berorganisasi, termasuk kehidupan berkarya dalam organisasi bisnis, aspek motivasi kerja mutlak mendapat perhatian serius dari para manajer. Terdapat empat pertimbangan utama yaitu: Pertama, Filsafat hidup manusia berkisar pada prinsip “quit pro quo”. Kedua, Dinamika kebutuhan manusia sangat kompleks dan tidak hanya bersifat materi, akan tetapi juga bersifat psikologis. Ketiga, Tidak ada titik jenuh dalam pemuasan kebutuhan manusia. Keempat, Perbedaan BISNIS, Vol 6, No. 1 ,Juni 2018 
karakteristik individu dalam organisasi atau perusahaan, mengakibatkan tidak adanya satupun teknik motivasi yang sama efektifnya untuk semua orang dalam organisasi juga untuk seseorang pada waktu dan kondisi yang berbeda-beda.

\section{Kinerja}

Kata kinerja (perform) berasal dari kata "per" yang berarti dari atau menurut dan "form" yang berarti cara atau metode melakukan sesuatu yang memerlukan kecakapan.(Al Alwani, 2005: 170) Dalam kamus ekonomi kinerja adalah istilah umum yang menggambarkan tindakan atau aktifitas suatu organisasi selama periode tertentu, seiring dengan referensi pada sejumlah standart. Seperti biaya masa lalu atau biaya yang diproyeksikan, dasar efisiensi, pertanggung jawaban manajement dan semacam-macamnya (Winarno, 2003: 346).

Kinerja merupakan salah satu faktor yang mendukung tercapainya tujuantujuan yang ditetapkan oleh perusahaan atau organisasi. Karyawan dituntut untuk memberikan hasil kerja yang optimal untuk organisasi sesuai dengan tanggung jawab tugas yang telah diberikan oleh perusahaan. Prestasi kerja yang baik dari karyawan merupakan hasil dari kinerja karyawan dalam mencapai standar kinerja yang telah ditetapkan oleh perusahaan. Sedangkan kinerja karyawan adalah tingkatan dimana para karyawan mencapai persyaratan-persyaratan pekerjaan. Kinerja (performance) mengacu pada kadar pencapaian tugas-tugas yang membentuk sebuah pekerjaan karyawan. Kinerja merefleksikan seberapa baik karyawan memenuhi persyaratan sebuah pekerjaan (Simamora, 2004: 409).

Wirawan menjelaskan bahwa kinerja merupakan hasil sinergi dari sejumlah faktor yaitu, faktor lingkungan internal organisasi, factor lingkungan eksternal, dan faktor internal karyawan atau pegawai. Faktor internal pegawai, Faktor faktor dari dalam diri pegawai yang merupakan faktor bawaan dari lahir dan faktor yang diperoleh ketika ia berkembang. Faktor bawaan seperti bakat, sifat pribadi, serta keadaan fisik dan kejiwaan. Faktor yang diperoleh seperti pengetahuan, keterampilan, etos kerja, pengalaman kerja, dan motivasi kerja. Semakin tinggi faktor-faktor internal tersebut, makin tinggi pula kinerja pegawai.

Faktor lingkungan internal organisasi Pegawai memerlukan dukungan organisasi tempat ia bekerja, dukungan tersebut memengaruhi tinggi rendahnya 
kinerja pegawai. Faktor internal organisasi misalnya strategi organisasi, dukungan sumber daya yang diperlukan untuk melaksanakan pekerjaan, serta sistem manajemen dan kompensasi.

Faktor lingkungan eksternal organisasi Faktor-faktor lingkungan eksternal organisasi adalah keadaan, kejadian, atau situasi yang terjadi di lingkungan eksternal organisasi yang memengaruhi kinerja karyawan. Misalnya krisis ekonomi dan menurunnya nilai gaji karyawan (Wirawan, 2009: 7).

Menurut Shore, dkk (1990) dalam Arnolds (2002:700) kinerja dapat diukur dengan tujuan kerja (performance intentions) dari manajer puncak maupun karyawan frontline. Karyawan frontline adalah karyawan yang berinteraksi langsung dengan klien atau pelanggan. Contoh karyawanfrontline adalah teller bank, sekretaris, pegawai, petugas keamanan, staf kantor dll. Tujuan-tujuan yang spesifik merupakan kekuatan motivasi yang kuat. Tujuan kerja yang spesifik dan menantang bagi karyawan adalah hal yang terbaik untuk meningkatkan kinerja (Robbins 2008:239).

Berdasarkan beberapa teori di atas maka dapat disimpulkan bahwa kinerja yang baik dapat dimunculkan melalui niat atau tujuan kerja dari setiap individu. Niat atau tujuan kerja masing-masing individu dapat dipengaruhi oleh faktor eksternal maupun internal dari setiap individu. Untuk mencapai kinerja yang optimal, tujuan dan niat kerja dari dalam karyawan harus sesuai dengan dengan tanggung jawab, standar kinerja, dan persyaratan-persyaratan yang telah ditetapkan oleh perusahaan.

\section{Kerangka Konseptual Penelitian}

Kerangka konseptual pada penelitian ini dapat divisualkan sebagai berikut:

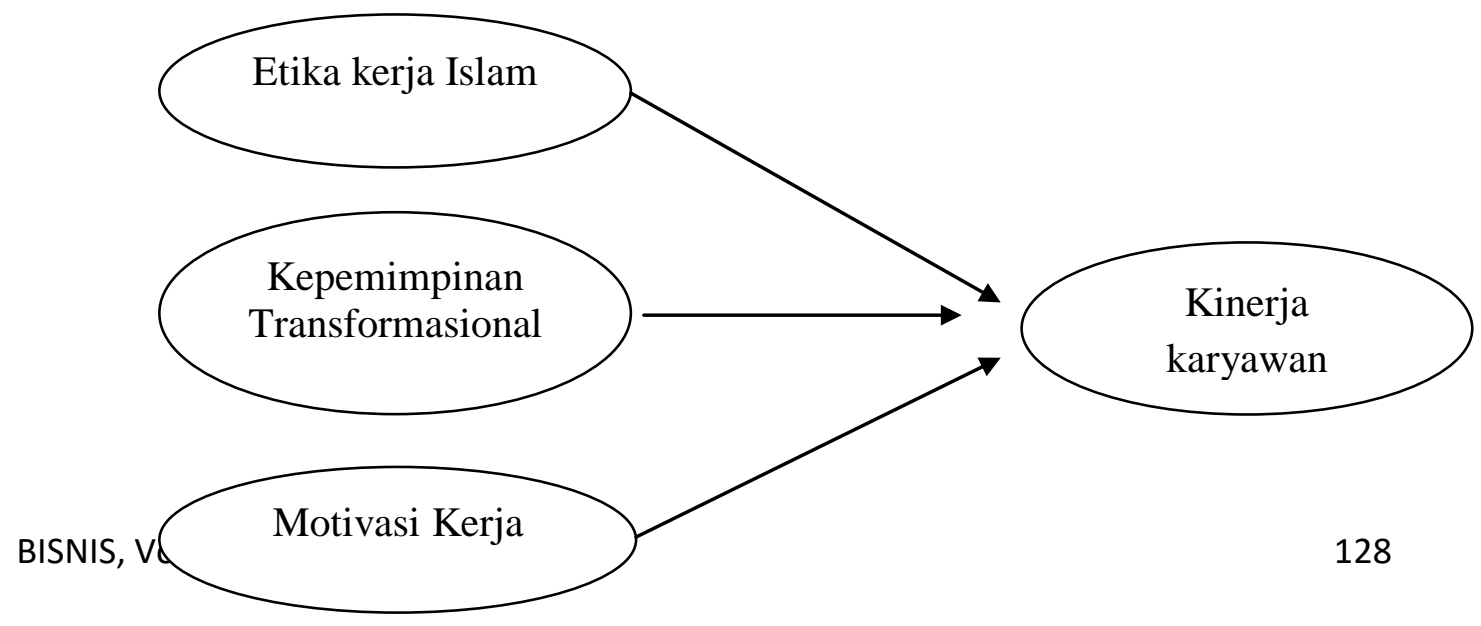




\section{Penelitian Terdahulu}

1. Muhammad Nouman Shafique et. al. melakukan penelitian dengan judul "The Influence of Islamic Work Ethics on Job Satisfaction and Organization Commitment" dengan menghasilkan kesimpulan bahwa etika kerja Islam berpengaruh positif terhadap kepuasan kerja dan kmitmen organisasi, penelitian tersebut juga mengungkapkan bahwa dorongan terhadap etika kerja Islam akan mengalami peningkatan seiring dengan bertambahnya usia, tingkat pendidikan dan pengalaman kerja.

2. Wahibur Rokhman melakukan penelitian di 10 lembaga keuangan syariah mikro finance di kota Demak dengan judul "The Effect of Islamic Work Ethics on Work Outcomes" dan menyimpulkan bahwa etika kerja Islam berpengaruh positif terhadap kepuasan kerja dan komitmen organisasi dan tidak berpengaruh terhadap turnover intention.

3. Alfa Shafissalam dan Misbahuddin Azzuhri melakukan penelitian dengan judul "Pengaruh Etos Kerja Islami Terhadap Kinerja Karyawan Pada Koperasi Agro Niaga Indonesia (Kanindo) Syariah Jawa Timur” dan menyimpulkan bahwa etika kerja Islam tidak berpengaruh terhadap kinerja karyawan Kanindo Syariah.

4. Fatima Bushra et. al. melakukan penelitian dengan judul "Effect of Transformational Leadership on Employees' Job Satisfaction and Organizational Commitment in Banking Sector of Lahore (Pakistan)" dan menyimpulkan bahwa kepemimpinan transformasional berpengaruh positif terhadap kepuasan kerja dan komitmen organisasi. 
5. Syahid Natsir melakukan penelitian dengan judul "Pengaruh Gaya Kepemimpinan Transaksional Dan Transformasional Terhadap Perilaku Kerja dan Kinerja Perbankan di Sulawesi Tengah" dan berakhir dengan kesimpulan bahwa gaya kepemimpinan transformasional berpengaruh negative terhadap kinerja karyawan.

\section{Hipotesis Penelitian}

Berdasarkan penjelasan dari rumusan masalah yang telah diuraikan di atas, maka peneliti mengajukan hipotesis sebagai berikut:

H1. Etika kerja Islam berpengaruh terhadap kinerja karyawan di KJKS BMT Logam Mulia Grobogan

H2. Kepemimpinan transformasional berpengaruh terhadap kinerja karyawan di KJKS BMT Logam Mulia Grobogan

H3. Motivasi kerja berpengaruh terhadap kinerja karyawan di KJKS BMT Logam Mulia Grobogan

\section{Metode Penelitian}

Penelitian ini menggunakan pendekatan kuantitatif karena lebih mengarahkan masalah menjadi suatu hubungan kausalitas sehingga hubungan antar variabel dapat dijelaskan. Penelitian ini termasuk dalam penelitian kausa, yang berdasarkan pada kejadian sebab akibat. Penelitian ini menitikberatkan pada pengujian hipotesis sehingga data yang digunakan harus terukur, dan akan menghasilkan kesimpulan yang dapat digeneralisasikan. Sedangkan metode yang digunakan adalah metode survei dengan membagikan kuisioner kepada karyawan BMT BMT Logam Mulia Grobogan.

Populasi adalah wilayah generalisasi yang terdiri atas: obyek/subyek yang mempunyai kualitas dan karakteristik tertentu yang ditetapkan oleh peneliti untuk dipelajari dan kemudian ditarik kesimpulannya (Sugiyono, 2008: 80). Populasi dari penelitian ini adalah karyawan tetap BMT Logam Mulia Grobogan yang berjumlah 34 karyawan.

Sampel adalah bagian dari jumlah dan karakteristik yang dimiliki oleh populasi tersebut. Dalam penelitian ini menggunakan teknik sampel saturation sampling. Sampel yang digunakan adalah sampel jenuh karena pengambilan 
Amirus Shodiq

anggota sampel dari populasi dilakukan secara keseluruhan yang ada dalam pospulasi itu. Sampel pada penelitian ini adalah karyawan BMT Logam Mulia Grobogan yang diambil secara keseluruhan oleh peneliti.

Dalam metode survey didesain dengan menggunakan pada skala likert, di mana skala likert digunakan untuk mengukur sikap, pendapat, dan persepsi seseorang atau sekelompok orang tentang fenomena sosial. Jawaban setiap item instrumen yang menggunakan skala likert mempunyai gradasi dari sangat positif sampai sangat negative.

Analisis data dilakukan dengan tiga tahap:

1. Uji reliabilitas dan Validitas

2. Uji Asumsi Klasik

3. Analisi regresi linier berganda

Analisis linier berganda hubungan secara linier antara dua atau lebih variabel independen (X1, X2, dan X3) dengan variabel dependen (Y). Analisis ini digunakan untuk mengetahui arah hubungan antara variable independen dengan variabel dependen, apakah masing-masing variable independen berhubungan positif atau negatif. Dalam penelitian ini menggunakan rumus persamaan regresi linier berganda untuk menganalisa data. Bentuk persamaan garis regresi linier berganda adalah sebagai berikut:

$$
\mathrm{Y}=\mathrm{a}+\mathrm{b} 1 \mathrm{X} 1+\mathrm{b} 2 \mathrm{X} 2+\mathrm{b} 3 \mathrm{X} 3+\mathrm{e}
$$

Dimana:

$\begin{array}{ll}\text { X1 } & \text { : Etika Kerja Islam } \\ \text { X2 } & \text { : Kepemimpinan Transformasional } \\ \text { X3 } & \text { : Motivasi Kerja } \\ \text { Y } & \text { : Kinerja karyawan } \\ \text { a } & \text { : Konstanta } \\ \text { b1, b2, b3 } & : \text { Koefisien regresi } \\ \text { e } & \text { : standar error }\end{array}$




\section{Analisis Data Dan Pembahasan}

KSPS BMT Logam Mulia adalah koperasi simpan pinjam yang bergerak dilembaga keuangan mikro yang menggunakan prinsip syariah dalam menjalankan operasinya dengan sistem profit and sharing.

Kantor pusat KSPS BMT Logam Mulia di Klambu \{Jl. Raya Klambu No.10, Kab. Grobogan No. Telp. (0292) 7702700 atau (0292) 7701515\}.

KSPS BMT Logam Mulia mempunyai 7 cabang antara lain: Klambu, Grobogan, Babalan, Undaan Wates, Jekulo, Gubug, dan Dawe.

a. Kantor pusat Klambu, yang beralamat Jl. Raya Klambu No. 30, Klambu Grobogan (58154) Jawa Tengah Telp (0292) 4274025.

b. Kantor cabang Undaan Wates yang beralamat Jl. Raya Purwodadi Kudus KM 7 Undaan Kudus.

c. Kantor cabang Jekulo yang beralamat Jl. Raya Kudus - Pati KM 10 No. 211 Klaling Jekulo Kudus Telp (0291) 3305033.

d. Kantor cabang Dawe yang beralamat Jl. Raya Colo - Kudus Km 12 Dawe Kudus Telp (0291) 4259060.

e. Kantor cabang Babalan yang beralamat di Jl. Raya Purwodadi-Kudus Telp (0292) 3305031.

f. Kantor cabang Grobogan yang beralamat di Jalan P. Puger nomor 57 Grobogan.

Kantor cabang di kecamatan Gubug, dengan alamat jalan Bhayangkara nomor 64 kecamatan Gubug, di kabupaten Grobogan.

\section{Uji Asumsi Klasik}

Sebelum dilakukan pengujian hipotesis dengan uji $\mathrm{F}$ dan uji t terlebih dahulu dilakukan uji penyimpangan asumsi klasik. Pengujian ini dilakukan untuk menguji validitas dari hasil analisis regresi linier berganda. Adapun pengujian yang digunakan adalah Uji Normalitas, Uji Autokorelasi, uji multikolinieritas, uji heteroskedastisitas.

\section{Uji Normalitas}

Uji normalitas bertujuan untuk menguji apakah dalam model regresi, variabel tergantung dan variabel bebas keduanya mempunyai distribusi normal atau 
Amirus Shodiq

tidak. Model regresi yang baik adalah memiliki distribusi data normal atau mendekati normal. Untuk menguji normalitas data digunakan digram Normal P-Plot. Hasil pengujian normalitas dapat ditunjukkan pada gambar berikut :

\section{Gambar 1}

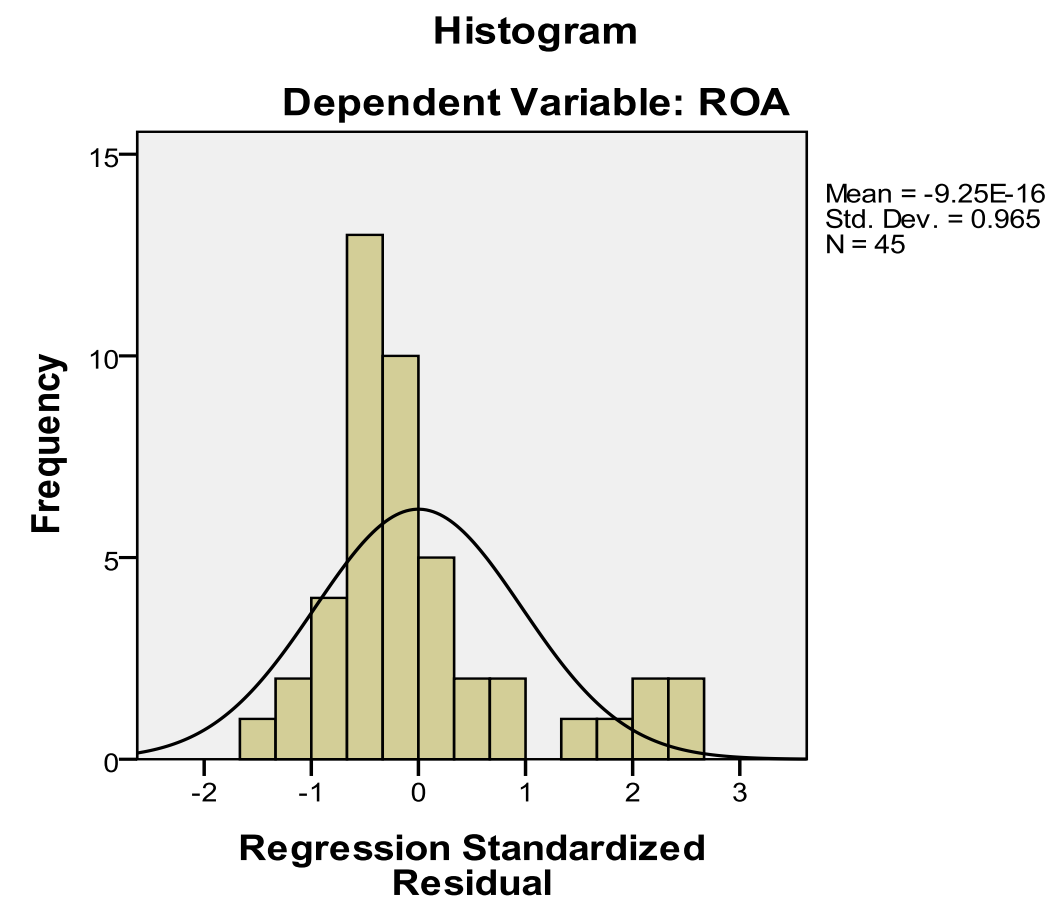




\section{Gambar2}

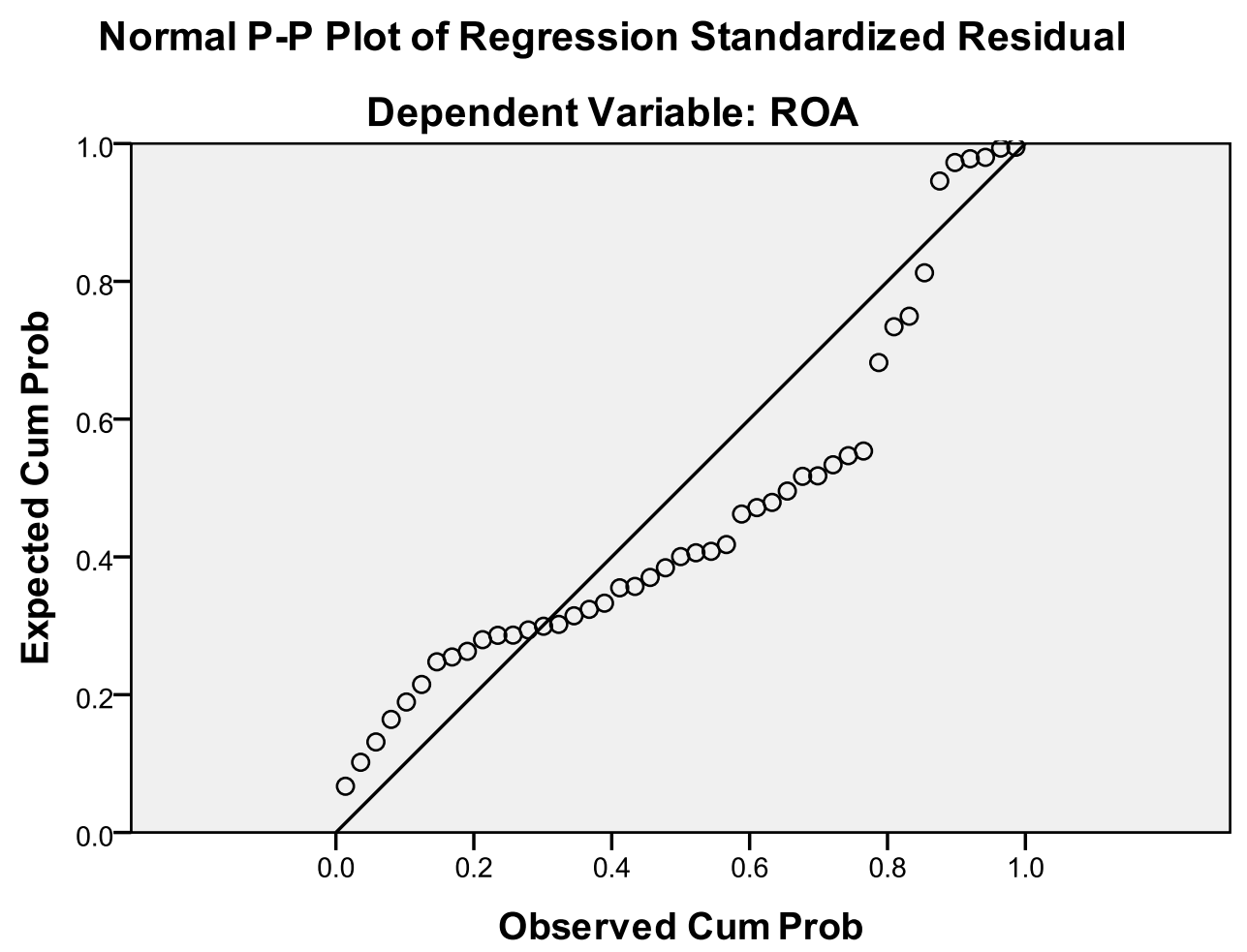

Berdasarkan gambar 1 dan 2 dapat diketahui bahwa titik-titik yang terbentuk menyebar di sekitar garis diagonal pada kurva hitogram serta kurva normal P-plot membentuk gambar lonceng. Dengan demikian data dalam penelitian ini telah berdistribusi normal.

Untuk lebih menguatkan grafik dilakukan uji statistic yaitu Uji Kolgorov Smirnov atau Uji K-S, pengujian ini dilakukan dengan membuat hipotesis:

Ho : Data Residual berdistribusi normal

Ha : Data Residual tidak berdistribusi normal.

Dengan kriteria uji :

Ho ditolak bila asymptotic signifikan value uji kolmogorov-smirnov $<0,05$. 
Gambar 3

\section{Hasil Uji Kolmogorv Smirnov}

\begin{tabular}{|ll|r|}
\hline \multicolumn{2}{|c|}{ One-Sample Kolmogorov-Smirnov Test } \\
\hline $\mathrm{N}$ & $\begin{array}{c}\text { Unstandardized } \\
\text { Residual }\end{array}$ \\
Normal Parameters ${ }^{\mathrm{a}, \mathrm{b}}$ & Mean & 42 \\
& Std. Deviation & .0000000 \\
Most Extreme Differences & Absolute & .38835669 \\
& Positive & .160 \\
& Negative & .160 \\
Kolmogorov-Smirnov Z & & -.138 \\
Asymp. Sig. (2-tailed) & & 1.037 \\
\hline
\end{tabular}

a. Test distribution is Normal.

b. Calculated from data.

Dari table diatas kita dapat menyimpulkan bahwa nilai KolmogorovSmirnov sebesar 1, 037 dan tingkat signifikansi 0,232 yang lebih besar dari 0,05. Dengan demikian Ho diterima yang artinya data dalam penelitian ini berdistribusi normal dan hasil ini konsisten dengan uji sebelumnya.

\section{Uji Heteroskedastisitas}

Heteroskedastisitas adalah variasi residual tidak sama untuk semua pengamatan. Uji ini dimaksudkan untuk mengetahui apakah terjadi penyimpangan model karena varian gangguan berbeda antara satu observasi ke observasi lain. Untuk mendeteksi adanya gejala heteroskedastisitas dalam model persamaan regresi, dapat menggunakan gambar/chart model scatter dengan program SPSS. Model regresi akan heteroskedastik bila data akan berpencar disekitar angka nol (0 pada sumbu y) dan tidak membentuk suatu pola atau trend garis tertentu (Ghozali, 2001), Hasil pengujian heteroskedastisitas dapat ditunjukkan pada gambar berikut: 


\section{Gambar 4.}

\section{Scatterplot}

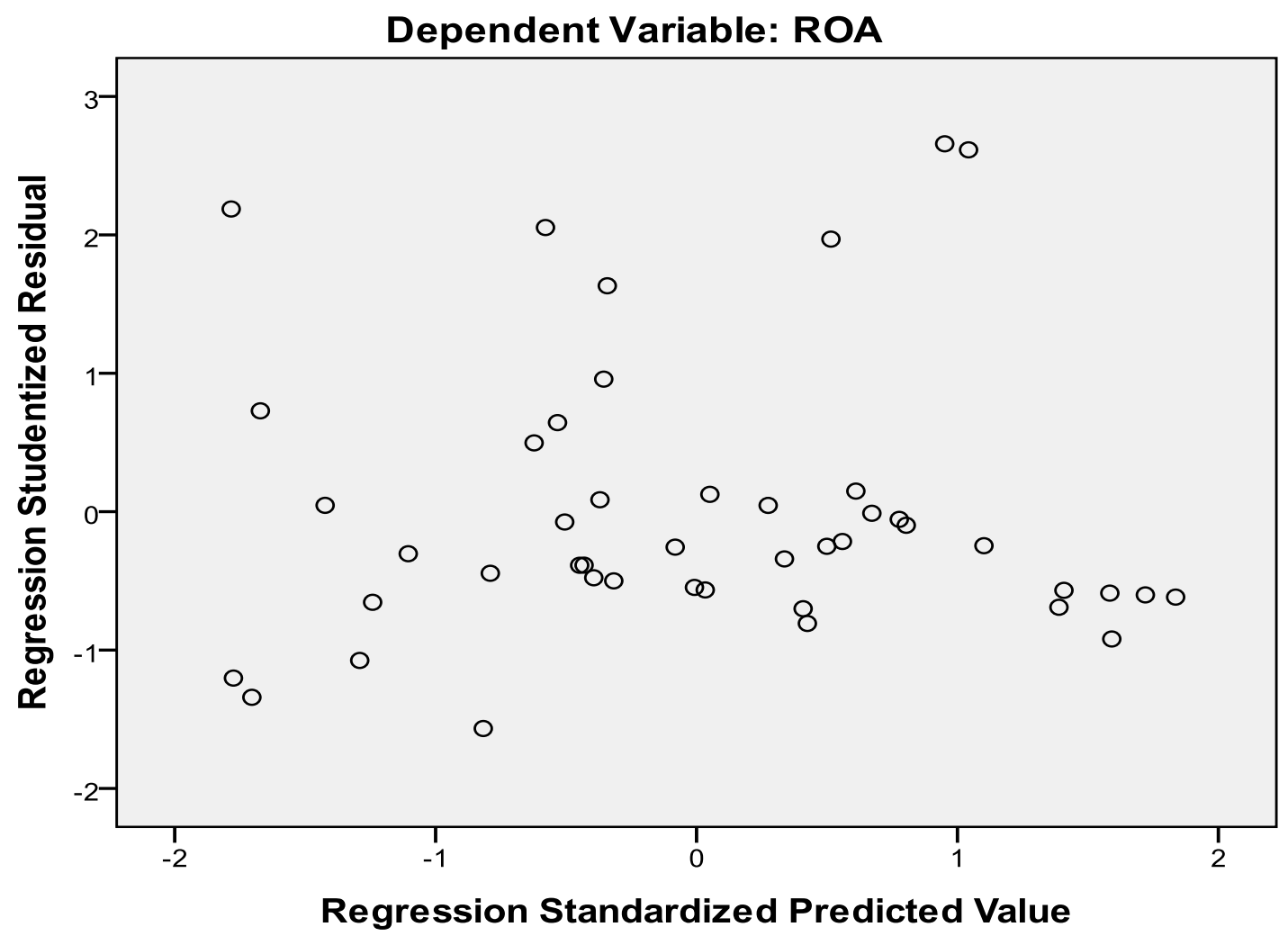

Dari gambar diatas menunjukkan bahwa sebaran data residual tidak membentuk pola tertentu dan menyebar di sekitar nol. Dengan demikian model regresi yang digunakan tidak terjadi heteroskedastisitas.

\section{Uji Multikolinieritas}

Multikolinieritas adalah situasi adanya multi korelasi diantara variabel bebas satu dengan yang lainnya atau dengan kata lain diantara variabel-variabel bebas tersebut dapat dibentuk hubungan antara variabel yang satu dengan variabel yang lainnyaMenurut (Ghozali, 2001), untuk menguji ada tidaknya gejala multikolinieritas digunakan VIF (Variance Inflacition Factor). Jika nilai VIF dibawah 10 maka model regresi yang diajukan tidak terdapat gejala multikolinieritas, begitu sebaliknya jika VIF lebih besar 10 maka terjadi gejala multikolinieritas. Hasil uji multikolinieritas dapat ditunjukkan pada tabel berikut: 
Amirus Shodiq

\begin{tabular}{|c|c|c|c|}
\hline \multirow{2}{*}{\multicolumn{2}{|c|}{ Model }} & \multicolumn{2}{|c|}{ Collinearity Statistics } \\
\hline & & Tolerance & VIF \\
\hline \multirow[t]{4}{*}{1} & (Constant) & & \\
\hline & EKI & .910 & 1.099 \\
\hline & $\mathrm{KT}$ & .822 & 1.217 \\
\hline & MK & .899 & 1.113 \\
\hline
\end{tabular}

Melihat hasil besaran korelasi antar variable independen tampak bahwa variable Kepemimpina Tranformasional yang memiliki korelasi cukup tinggi dengan variable Motivasi Kerja dengan tingkat korelasi sebesar -0,315 atau sekitar 31,5\%. Oleh karena korelasi ini masih dibawah 95\%, maka dapat dikatakan tidak terjadi multikolinieritas yang serius.

Hasil perhitungan nilai Tolerance juga menunjukkan tidak ada variable independen yang memiliki nilai Tolerance kurang dari 0.10 yang berarti tidak korelasi antar variable independen yang nilainya lebih dari 95\%. Hasil perhitungan nilai VIF juga menunjukkan hal yang sama, tidak ada satu variable independen yang yang memiliki nilai VIF lebih dari 10 . jadi dapat disimpulkan bahwa tidak ada multikolinieritas antar variable independen dalam model regresi.

\section{Uji Autokorelasi}

Pengujian ada tidaknya autokorelasi dilakukan dengan menggunakan metode Durbin-Watson. Adapun cara mendeteksi terjadi autokorelasi dalam model analisis regresi dengan menggunakan DW menurut (Ghozali, 2001) dapat dijelaskan sebagai berikut:

\section{Gambar 6}

Nilai Durbin Watson (d)

\begin{tabular}{|l|r|}
\hline Model & Durbin-Watson \\
\hline 1 & 2.360 \\
& \\
\hline
\end{tabular}


Nilai Durbin Watson (DW Statistik) dari hasil analisis regresi sebesar 2,360 (table 4.5). Dengan demikian, nilai Durbin Watson tersebut berada pada interval 0 sampai dengan 1,60, sehingga dapat dipastikan bahwa model regresi linier berganda tersebut tidak terjadi gejala autokorelasi.

\section{Analisis Regresi Linier Berganda}

Hasil pengujian terhadap model regresi berganda terhadap faktor-faktor yang mempengaruhi Kinerja Karyawan pada BMT Lobam Mulia. Hasil analisis regresi dapat ditunjukkan pada tabel berikut :

\section{Gambar 7}

\section{Coefficients $^{\mathbf{a}}$}

\begin{tabular}{|c|c|c|c|c|c|c|}
\hline \multirow{2}{*}{\multicolumn{2}{|c|}{ Model }} & \multicolumn{2}{|c|}{ Unstandardized Coefficients } & \multirow{2}{*}{$\begin{array}{c}\text { Standardized } \\
\text { Coefficients } \\
\text { Beta }\end{array}$} & \multirow[b]{2}{*}{$\mathrm{T}$} & \multirow[b]{2}{*}{ Sig. } \\
\hline & & $\mathrm{B}$ & Std. Error & & & \\
\hline \multirow[t]{4}{*}{1} & (Constant) & -.002 & 1.598 & & -.001 & .999 \\
\hline & EKI & -.100 & .147 & -.098 & -.680 & .500 \\
\hline & KT & .008 & .003 & .428 & 2.830 & .007 \\
\hline & MK & -.887 & .311 & -.412 & -2.849 & .007 \\
\hline
\end{tabular}

a. Dependent Variable: KK

Pada penelitian ini digunakan model persamaan regresi linear berganda sebagai berikut :

$\mathrm{KK}=\alpha_{+} \beta_{1} \mathrm{EKI}+\beta_{2} \mathrm{KT}+\beta_{3} \mathrm{MK}+\ni$

Dengan memperhatikan model regresi dan hasil regresi linear berganda maka didapat persamaan faktor-faktor yang mempengaruhi Kinerja Karyawan pada BMT Logam Mulia sebagai berikut :

$\mathrm{KK}=-0,002-0,100 \mathrm{EKI}+0,008 \mathrm{KT}-0,887 \mathrm{MK}+\ni$

Berdasarkan nilai p-value tabel 4.6 di atas, bahwa koefisien dari variabel Etika Kerja Islam tidak berpengaruh signifikan terhadap Kinerja Karyawan karena nilainya diatas 5\%, sedangkan variable Kepemimpinan Transformasional dan Motivasi Kerja berpengaruh signifikan terhadap Kinerja Karyawan, karena nilainya di bawah $5 \%$.

Variable yang paling besar pengaruhnya adalah variable 
Kepemimpinan Transformasional dengan nilai koefisien sebesar 0,008 (arah pengaruh koefisien positif)

Pengujian hipotesis dalam penelitian ini menggunakan uji signifikansi simultan atau uji $\mathrm{F}$ dan uji signifikansi parameter individual atau uji t. Uji $\mathrm{F}$ dilakukan untuk membuktikan pengaruh secara serentak variabel bebas terhadap variabel terikat, sedangkan uji t digunakan untuk membuktikan pengaruh secara parsial variabel bebas terhadap variabel terikat.

\section{Uji Signifikansi Simultan}

Uji F digunakan untuk menguji signifikansi pengaruh variabel bebas secara simultan terhadap variabel terikat. Langkah-langkah yang dilakukan dalam pengujian hipotesis pertama adalah sebagai berikut :

a. Menentukan formula hipotesis

Ho: Tidak ada pengaruh yang signifikan, EKI $\left(\mathrm{X}_{1}\right)$, KT $\left(\mathrm{X}_{2}\right), \mathrm{MK}$ (X3) secara simultan terhadap KK (Y)

Ha: Ada pengaruh yang signifikan, EKI $\left(\mathrm{X}_{1}\right), \mathrm{KT}\left(\mathrm{X}_{2}\right)$, MK (X3) secara simultan terhadap KK (Y)

b. Menentukan besarnya nilai F hitung dan Signifikansi F (Sig-F)

c. Menentukan level signifikansi 5\%

d. Menentukan Kriteria pengujian hipotesis

- Ho diterima jika probabilitas $(\operatorname{sig}-\mathrm{F})>0,05$

- Ho ditolak jika probabilitas $($ Sig-F) $<0,05$

- Hasil Uji F ditunjukkan pada tabel berikut:

\section{Gambar 8}

Hasil uji F (ANOVA)

\begin{tabular}{|ll|r|r|r|r|r|}
\hline \multicolumn{2}{|c|}{ ANOVA $^{\text {b }}$} & Df & Mean Square & F & Sig. \\
\hline 1 & Sum of Squares & Df & 3.080 & 2.027 & 4.090 & $.013^{\mathrm{a}}$ \\
& Regression & 20.317 & 41 & .496 & & \\
Residual & 26.397 & 44 & & & \\
Total & & & &
\end{tabular}

a. Predictors: (Constant), MK, EKI, KT

b. Dependent Variable: KK

Berdasarkan tabel 4.7 di atas di dapat $\mathrm{F}$ hitung sebesar 4,090 dengan 
probabilitas sebesar 0,013 yang nilainya lebih kecil dari 0,05 maka Ho ditolak dan menerima Ha (hipotesis ditolak). Ini menunjukkan bahwa EKI (X1), KT (X2), dan MK (X3) secara simultan berpengaruh terhadap Kinerja Karyawan pada BMT Logam Mulia.

\section{Gambar 9}

Model Summary ${ }^{b}$

\begin{tabular}{|l|r|r|lr|}
\hline Model & R & R Square & \multicolumn{2}{|c|}{ Adjusted R Square } \\
\hline 1 & $.674^{\mathrm{a}}$ & .455 & & \\
& & & & \\
\hline
\end{tabular}

a. Predictors: (Constant), MK, EKI, KT

b. Dependent Variable: KK

Dari tabel 4.8 di atas dapat diketahui koefisien determinasi (Adjusted $R$ Square) sebesar 0,439 Dengan nilai koefisien determinasi sebesar 0,439, maka dapat diartikan bahwa 43,9\% KK dapat dijelaskan oleh ketiga variabel bebas yang terdiri dari EKI (X1), KT (X2), dan MK (X3), Sedangkan sisanya sebesar 56,1\% dipengaruhi oleh variabel lain yang tidak dimasukkan dalam model regresi

\section{Uji signifikansi parameter individual}

Uji t digunakan untuk mengetahui pengaruh secara parsial variabel bebas terhadap variabel terikat. Pengujian ini yaitu dengan membandingkan nilai probabilitas atau p-value (sig-t) dengan taraf signifikansi 0,05. Jika nilai p-value lebih kecil dari 0,05 maka Ha diterima, dan sebaliknya jika p-value > 0,05 maka Ha ditolak.

Hasil uji t pada variabel Inflasi $\left(\mathrm{X}_{1}\right)$ seperti pada tabel 4.9 di atas diperoleh t hitung sebesar $-0,680$ dengan probabilitas sebesar 0,500 yang nilainya di atas 0,05. Dengan demikian H1 ditolak, artinya tidak ada pengaruh yang signifikan Etika Kerja Islam (X1) secara parsial terhadap Kinerja Karyawan (Y). Dengan demikian temuan ini tidak mendukung hipotesis penelitian yang menyatakan bahwa "Etika Kerja Islam berpengaruh negatif terhadap Kinerja Karyawan BMT Logam Mulia”. 
Hasil uji t pada variabel Kepemimpinan Transformasional pada tabel 4.6 diatas diperoleh t hitung sebesar 2,830 dengan probabilitas sebesar 0,007 yang nilainya jauh dibawah 0,05. Dengan demikian H2 diterima, artinya terdapat pengaruh yang signifikan variabel Kepemimpinan Transformasional (X2) secara parsial terhadap Kinerja Karyawan (Y).

Hasil uji t pada variabel Motivasi Kerja (X3) seperti pada tabel 4.6 diatas diperoleh t hitung sebesar -2,849 dengan probabilitas sebesar 0,007 yang nilainya dibawah 0,05. Dengan demikian $\mathbf{H 3}$ diterima, artinya terdapat pengaruh yang signifikan Motivasi Kerja (X3) secara parsial terhadap Kinerja Karyawan (Y).

Hasil dari pengujian statistik ternyata tidak semuanya mendukung hipotesis. Secara garis besar dapat dijelaskan bahwa hasil pengujian pada faktor makro ekonomi yang diproksi dengan Etika Kerja Islam, Kepemimpinan Transformasional dan Motivasi Kerja menunjukkan bahwa Etika Kerja Islam tidak berpengaruh terhadap Kinerja Karyawan BMT Logam Mulia, sedangkan Kepemimpinan Transformasional dan Motivasi Kerja berpengaruh terhadap Kinerja Karyawan BMT Logam Mulia.

Secara teoritis, hasil penelitian pada perbankan Syariah di Indonesia cenderung lebih sesuai dengan Teori Ekonomi Islam murni yang menjelaskan bahwa pada ekonomi Islam lebih mengutamakan perputaran uang pada sektor riil, hal ini juga selaras dengan produk-produk bank Syariah yang fokus di sector riil seperti pembiayaan musyarakah ataupun mudharabah.

Dalam Islam tidak mengenal uang sebagai bentuk investasi melainkan hanya sebagai alat tukar, sehinga uang harus diputar untuk usaha riil yang mendatangkan manfaat. Berbeda dengan teori konvensional maupun teori campuran dimana yang menjelaskan bahwa meskipun bank syariah bebas bunga namun pada kondisi dual banking system akan tetap terpengaruh.

Hasil penelitian ini mendukung penelitian yang pernah dilakukan Ayu Yanita Sahara (2013) yang menyatakan bahwa variabel-variabel marko ekonomi dalam hal ini Etika Kerja Islam dan Kepemimpinan Transformasional, secara simultan menunjukkan pengaruh yang signifikan terhadap Kinerja Karyawan BMT Logam Mulia. 


\section{SIMPULAN}

Berdasarkan hasil analisis dan pembahasan yang telah dijelaskan di Bab terdahulu, maka kesimpulan dari penelitian ini adalah:

1. Secara parsial Etika Kerja Islam (X1) menunjukkan tidak adanya pengaruh yang signifikan terhadap kinerja karyawan di BMT Logam Mulia Grobogan, dengan probabilitas signifikansi sebesar 0,500 yang jauh diatas 0,05 .

2. Secara parsial Kepemimpinan Transformasional (X2) menunjukkan pengaruh yang signifikan terhadap kinerja karyawan di BMT Logam Mulia Grobogan, dengan probabilitas signifikansi sebesar 0,007 yang jauh diatas 0,05 .

3. Secara parsial Motivasi kerja (X3) menunjukkan pengaruh yang signifikan terhadap kinerja karyawan di BMT Logam Mulia Grobogan, dengan probabilitas signifikansi sebesar 0,007 yang jauh diatas 0,05.

Secara simultan Etika Kerja Islam, kepemimpinan Transformasional, Motivasi kerja menunjukkan pengaruh yang signifikan terhadap kinerja karyawan di BMT Logam Mulia Grobogan, dengan probabilitas signifikansi sebesar 0,500 yang jauh diatas 0,05.Dengan nilai $\mathrm{R}$ square sebesar 0,439, dapat diartikan bahwa 43,9\% dapat dijelaskan oleh ketiga variable bebas sedangkan sisanya sebesar $56,1 \%$ dipengaruhi oleh variable-variabel yang tidak dimasukkan dalam model regresi. 


\section{DAFTAR PUSTAKA}

Agoes, Surisnodan I CenikArdana, 2009, Etika Bisnis dan Profesi, Jakarta: SalembaEmpat.

Ahmad, Muhammad Shakil, 2011, "Work Ethics: An Islamic Prospective", International Journal of Human Sciences, Vol. 8, Issue. 1.

Ahmad, Shukri dan Musa Yusuf Owoyemi, (2012), “The Concept of Islamic Work Ethic: An Analysis of Some Salient Points in the Prophetic Tradition", International Journal of Business and Social Science, Vol. 3, No. 20.

Ali, Abbas, (2001), "Scaling an Islamic Work Ethic", The Journal of Social Psychology, 128 (5), P. 575-583

Ali, J. A. dalam Wahibur, (2010) "The Effect of Islamic Work Ethics on Work Outcomes", Electronic Journal of Business Ethics and Organization Studies, Vol. 15 No. 1.

Bambang Rudito dan Melia Famiola, Etika Bisnis dan Tanggung Jawab Sosial Perusahaan di Indonesia, (Bandung: Rekayasa Sains, 2007)

Bass, B. M., \& Riggio, R. E. (2006). Transformational Leadership Second Edition. New Jersey: Lawrence Erlbaum Associates.

Bushra et. Al. 2011. "Effect of Transformational Leadership on Employees' Job Satisfaction and Organizational Commitment in Banking Sector of Lahore (Pakistan)”. International Journal of Business and Social Science, Vol. 2. No. 18. Oktober 2011.

Ekaningsih, Ana Sri, (2014), "The Effect of Transformational Leadership on the Employees' Performance through Intervening Variables of Empowerment, Trust, and Satisfaction (A Study on Coal Companies in East Kalimantan)", Europian Journal of Business and Management, Vol. 6. No. 22.

Ghozali, Imam, 2002, Aplikasi Analisis Multivariate dengan program SPSS, Semarang: Bada Penerbit Universitas Diponegoro.

Griffin and Rafferty. (2004). "Dimensions of Transformational Leadership: Conceptual and Empirical Extensions". The Leadership Quarterly, 15 (2004).

Hasibuan, Malayu S. P. (1990), Manajemen Sumber Daya Manusia, Jakarta: CV Haji Masagung. 
Indica, I Wayan Marsalia, (2013), "Pengaruh Etos Kerja Islami Dan Gaya Kepemimpinan Transformasional Terhadap Komitmen Organisasional Dan Kinerja Karyawan (Studi Pada Waroeng Stike And Shake di Kota Malang)”. Jurnal Ilmiah Mahasiswa FEB Universitas Brawijaya, Vol. 1. No. 2.

Luthas, Fred. (2006). Perilaku Organisasi Edisi sepuluh. Yogyakarta: Penerbit ANDI.

Manullang, M. (1982), Dasar-Dasar Manajemen, Jakarta: Ghalla Indonesia.

Mustaq Ahmad, EtikaBisnis dalam Islam,Terj. Rahman Samson, Business Ethics in Islam(Jakarta:Pustaka Al-Kautsar, 2003).

Natsir, Syahir. (2005). "Pengaruh Gaya Kepemimpinan Transaksional Dan Transformasional Terhadap Perilaku Kerja dan Kinerja Perbankan di Sulawesi Tengah.” Jurnal Majalah Ekonomi. Vol. 14, NO. 1, April 2005.

R Robbins, S. P., \& Judge, T. A. (2008). Perilaku Organisasi. Edisi 12. Jakarta: Salemba Empat.

Rokhman Wahibur. (2010) "The Effect of Islamic Work Ethics on Work Outcomes", Electronic Journal of Business Ethics and Organization Studies, Vol. 15 No. 1.

Shafique, Muhammad Nouman, et. Al. 2015.'T he Influence of Islamic Work Ethics on Job Satisfaction and

Shafissalam, Alfa dan Misbahuddin Azzuhri, "pengaruh etos kerja islami terhadap kinerja karyawan Pada koperasi agro niaga indonesia (kanindo) syariah Jawa timur"

Simamora, H. (2004). Manajemen Sumber Daya Manusia. Yogyakarta: STIE YKPN.

Statistik Perbankan Syariah, Juni 2015. Bank Indonesia.

Sugiyono, 2008, Metode Penelitian Bisnis, Bandung: Alfabeta.

Suharsimi Arikunto, 2010, Prosedur Penelitian Suatu Pendekatan Praktik, Jakarta: Rineka Cipta.

Wirawan. (2009). Evaluasi Kinerja Sumber Daya Manusia. Jakarta: Salemba

Empat. 